\title{
Inhibitors of Protein Synthesis Also Inhibit Lysosomal Proteolysis Studies Using Cystinotic Fibroblasts
}

Jess G. Thoene, Rosemary Lemons, Steven Boskovich, and Katherine Borysko

Metabolic Disease Program, Department of Pediatrics, University of Michigan, School of Medicine, Ann Arbor, Michigan 48109

\begin{abstract}
Cystine depleted cystinotic fibroblasts incubated in cystine-free medium accumulate lysosomal-free cystine from the degradation of cystine-containing intracellular and extracellular proteins. In this report we have used this characteristic of these cells to study lysosomal proteolysis. We find that inhibitors of protein synthesis (cycloheximide, emetine, and puromycin) inhibit cystine accumulation from endogenous proteins and therefore act to inhibit lysosomal proteolysis of these proteins. However, cycloheximide does not inhibit cystine accumulation derived from the degradation of the extracellular disulfide-rich proteins, albumin and RNase, but lysosomal cystine accumulation derived from insulin is inhibited by cycloheximide. We conclude that a rapidly turning over protein may be required for the lysosomal degradation of intracellular and some extracellular proteins.
\end{abstract}

\section{Introduction}

The mechanisms that regulate proteolysis of endogenous and exogenous proteins remain poorly understood. Significant advances in the understanding of the degradation of endogenous proteins have occurred with the delineation of a nonlysosomal cytoplasmic system that has a neutral $\mathrm{pH}$ optimum and requires ATP (1), and in the discovery of ubiquitin, which is a 76-residue protein conjugated to short-lived proteins destined for nonlysosomal proteolysis under nutritionally complete conditions (2). Extracellular proteins that enter the cell by pinocytosis are degraded in lysosomes, as is also the case for some long-lived cellular proteins, and for proteins degraded during "step-down" conditions (2). The mechanism that targets intracellular proteins for lysosomal degradation under conditions of nutritional deprivation is not known, however, regulatory systems that balance protein synthesis and protein degradation appear to be required to maintain homeostasis throughout the cell cycle.

We present data showing that protein synthesis is required for the lysosomal degradation of endogenous proteins in human fibroblasts incubated under conditions of nutritional deprivation. This has been accomplished by using cells derived from patients with the autosomal recessive condition cystinosis,

An abstract of this work appeared in Pediatr. Res. 1984. 18:146.

Mr. Boskovich was the recipient of a University of Michigan Medical Student Research Fellowship funded by the Clinical Cancer Education Program. Address reprint requests to Dr. Thoene.

Received for publication 23 April 1984 and in revised form 24 September 1984.

J. Clin. Invest.

(C) The American Society for Clinical Investigation, Inc.

0021-9738/85/02/0370/07 \$1.00

Volume 75, February 1985, 370-376 whose lysosomes retain cystine from the degradation of cystinecontaining proteins (3-5). When such cells are incubated in cystine-free medium, lysosomal cystine only accumulates from the degradation of cystine-containing proteins (3). Lysosomal cystine accumulation is thus a direct measure of lysosomal proteolysis under these conditions. We find that although inhibitors of protein synthesis inhibit the lysosomal degradation of endogenous cystine-containing proteins, they do not inhibit the degradation of extracellular proteins taken up by pinocytosis. In the case of one receptor-mediated protein, insulin, lysosomal degradation is also inhibited. These results are consistent with the requirement for a short half-lived protein to participate in lysosomal degradation of endogenous proteins. We speculate that this or a similar protein may also be required for lysosomal degradation of insulin after dissociation from its receptor.

\section{Methods}

Diploid epithelial fibroblast cultures were derived from skin biopsies of patients with nephropathic cystinosis and maintained in a modified Ham's $F_{12}$ medium supplemented with $10 \%$ (vol/vol) fetal-bovine serum and incubated at $37^{\circ} \mathrm{C}$ in a humidified incubator flushed with an air/ $\mathrm{CO}_{2}$ (19:1) mixture. Control normal fibroblasts were purchased from the Human Genetic Mutant Cell Repository. Cystine-free medium was the same medium with cystine deleted. Cells were harvested by trypsin treatment and immediately broken by ultrasonic disruption in the presence of $5 \mathrm{mM} \mathrm{N}$-ethylmaleimide in $100 \mu \mathrm{M}$ phosphate buffer $\mathrm{pH}$ 7.4. Cell proteins were precipitated by the addition of one-fourth volume $12 \%$ sulphosalicylic acid and removed by centrifugation. The supernatant was analyzed for free $\left[{ }^{35} \mathrm{~S}\right]$ cystine by one-dimensional high voltage electrophoresis on paper (6), or for total free-cystine by a cystine-binding protein assay (7). Cell number was determined by a Coulter counter (Coulter Instruments, Inc., Hialeah, FL), model ZF, and cell protein by Lowry's method (8). Soluble radioactivity in cell supernatant or medium was determined by counting an aliquot in Aquasol (New England Nuclear, Boston, MA) in a Beckman LS-100 liquid scintillation counter (Beckman Instruments, Inc., Fullerton, CA). Radioactivity in protein was determined the same way after dissolving the pellet in 100 to $300 \mu \mathrm{l}$ of $0.1 \mathrm{~N} \mathrm{NaOH}$. Percent acid soluble radioactivity was determined by dividing the sum of the acid soluble radioactivity present in cells and medium by the total radioactivity present in the system. For cystine accumulation experiments, the cell protein pool was labeled by addition of $L-\left[{ }^{35} S\right]$ cystine $(\sim 500$ $\mathrm{Ci} / \mathrm{mMol}$, New England Nuclear) to complete medium containing 133 $\mu \mathrm{M}$ unlabeled cystine on dishes of confluent fibroblasts for periods as described in Results. Counting efficiency for $\left[{ }^{35} S\right]$ cystine was $94 \%$. Cystine-depleted cystinotic fibroblasts were prepared by incubation for $30 \mathrm{~min}$ in cystine-free medium containing $1 \mathrm{mM}$ cysteamine (6). Polyacrylamide gel electrophoresis was performed by the method of Laemmli (9) using a $4 \%$ stacking gel and a $10 \%$ analytical gel in the presence of $0.1 \%$ sodium dodecyl sulfate. Autoradiography was accomplished by exposure of the dried gel to x-ray film at $-70^{\circ} \mathrm{C}$ for $4 \mathrm{~d}$.

The effect of protein synthesis inhibitors on proteolytic activity of cystinotic fibroblast sonicates was determined using a previously described assay for cathepsin D (10). Sigma (Sigma Chemical Co., St. Louis, MO) bovine hemoglobin type II in citrate buffer at pH 3.0 was 
added to tubes containing aliquots of cell sonicates in a total volume of $0.8 \mathrm{ml}$ in the presence or absence of the inhibitors, and the mixture was incubated at $37^{\circ} \mathrm{C}$ for $10 \mathrm{~min}$, whereupon $0.5 \mathrm{ml}$ of chilled 0.6 $M$ trichloroacetic acid was added and the tubes placed on ice for an additional $10 \mathrm{~min}$. The tubes were then spun in a Beckman microfuge and the optical density of the supernatant measured at $280 \mathrm{~nm}$.

${ }^{125}$ I-insulin dissociation experiments were performed as previously described (11) by suspending cystinotic fibroblasts in Hepes binding buffer $\left(0.1 \mathrm{M}\right.$ Hepes, $0.12 \mathrm{M} \mathrm{NaCl}, 1.2 \mathrm{mM} \mathrm{MgSO}_{4}, 2.5 \mathrm{mM} \mathrm{KCl}, 10$ $\mathrm{mM}$ glucose, $1 \mathrm{mM}$ EDTA, and $10 \mathrm{mg} / \mathrm{ml}$ bovine serum albumin [BSA]) containing $0.3 \mathrm{ng} / \mathrm{ml}{ }^{125}$ I-insulin $\left(6.0 \times 10^{4} \mathrm{cpm} / \mathrm{ml}, 90 \mu \mathrm{Ci} /\right.$ $\mu \mathrm{g}$ ) at $15^{\circ} \mathrm{C}$ for $3 \mathrm{~h}$, then centrifuging and resuspending at a 1 to 20 dilution in unlabeled binding buffer with or without the addition of $100 \mu \mathrm{M}$ cycloheximide. At the indicated points the tubes were centrifuged and cell associated radioactivity determined with a Tracor gamma counter (TM Analytic, Elk Grove Village, IL). ${ }^{125}$ I-insulin binding was determined by incubation of a cystinotic fibroblast suspension in $0.6 \mathrm{ml}$ binding buffer containing $0.2-0.4 \mathrm{ng} / \mathrm{ml}{ }^{125} \mathrm{I}$-insulin $\left(4 \times 10^{4} \mathrm{cpm} / \mathrm{ml}\right)$ with and without the addition of $100 \mu \mathrm{M}$ cycloheximide. Binding was allowed to proceed at $15^{\circ} \mathrm{C}$ and at the indicated times, 200- $\mu$ l aliquots of the suspension were removed and centrifuged, the supernatant removed, and cell associated radioactivity in the cell pellet determined as described (12). Nonspecific binding was measured by adding excess unlabeled insulin $(100 \mu \mathrm{g} / \mathrm{ml})$ to parallel tubes and treating as above. The effect of cycloheximide on insulin receptors at the cell surface was determined by preincubating plates of cystinotic fibroblasts for $24 \mathrm{~h}$ at $37^{\circ} \mathrm{C}$ in complete medium containing $100 \mu \mathrm{M}$ cycloheximide, washing the plates four times with phosphate-buffered saline (PBS), adding binding buffer containing ${ }^{125} \mathrm{I}$-insulin $(0.5 \mathrm{ng} / \mathrm{ml}$, $8 \times 10^{4} \mathrm{cpm} / \mathrm{ml}$ ) and allowing binding to occur at $15^{\circ} \mathrm{C}$. Nonspecific binding was measured in parallel plates that also contained $100 \mu \mathrm{g} / \mathrm{ml}$ of unlabeled insulin. After a 5-h incubation the cells were washed four times in PBS and the cell monolayer dissolved in $1.0 \mathrm{ml}$ of $0.1 \mathrm{~N}$ $\mathrm{NaOH}$ for gamma counting. Specific binding was calculated as counts per minute per milligram of cell protein minus the cell associated radioactivity recovered in the presence of excess unlabeled insulin. Reagents were purchased from Sigma, Calbiochem-Behring, Div. of American Cyanamid, La Jolla, CA, New England Nuclear, or Eli Lilly, Indianapolis, IN (insulin), and were the best available grade. Statistical analyses were performed by paired $t$ test.

\section{Results}

Endogenous proteins. The effect of $100 \mu \mathrm{M}$ cycloheximide on lysosomal free- $\left[{ }^{35} \mathrm{~S}\right]$ cystine accumulation from the degradation of endogenous protein and on the loss of labeled $\left[{ }^{35} \mathrm{~S}\right]$ cystine from the acid precipitable pool and the increase in total acid soluble radioactivity is shown in Table $\mathrm{I}$. Cells were incubated for 4,24 , or $48 \mathrm{~h}$ in $\left[^{35} \mathrm{~S}\right]$ cystine-containing medium, treated with cysteamine to remove lysosomal $\left[{ }^{35} \mathrm{~S}\right]$ cystine, which had accumulated during the labeling procedure (6), placed in unlabeled cystine-free medium containing $10 \%$ (vol/vol) fetal bovine serum with or without the addition of $100 \mu \mathrm{M}$ cycloheximide, and harvested after an additional $24 \mathrm{~h}$ incubation. Cells and media were then analyzed as described in Methods. Cycloheximide significantly $(P<0.01$ to $P<0.10)$ inhibited lysosomal $\left[{ }^{35} \mathrm{~S}\right]$ cystine accumulation by $71 \%$ after a 48 -h label, to $77 \%$ after a 4 -h label. There was a significant $(P<0.05$ to $P<0.10$ ) increase in the amount of acid soluble radioactivity present after the 24-h incubation. However, the amount of $\left[{ }^{35} \mathrm{~S}\right]$ cystine present in the protein (acid precipitable) fraction treated with cycloheximide was not significantly different from controls for any duration of label.

In Fig. 1 is shown the concentration effect of cycloheximide on both the inhibition of lysosomal $\left[{ }^{35} \mathrm{~S}\right]$ cystine accumulation from cells labeled for $24 \mathrm{~h}$, and on the incorporation of $\left[{ }^{35} \mathrm{~S}\right]$ cystine into the protein pool during a 24-h label. Greater than $50 \%$ inhibition of lysosomal cystine accumulation was observed at a concentration of $5 \mu \mathrm{M}$, the lowest concentration tested, and maximum inhibition was produced at a concentration of 50 to $100 \mu \mathrm{M}$. The incorporation of $\left[{ }^{35} \mathrm{~S}\right]$ cyst(e)ine into the protein pool is also very sensitive to cycloheximide. A concentration of $5 \mu \mathrm{M}$ reduced incorporation by $97.8 \%$, and at a concentration of $100 \mu \mathrm{M}$, incorporation was inhibited by $>99 \%$.

Two other inhibitors of protein synthesis, emetine and puromycin, were also found to inhibit lysosomal $\left[{ }^{35} \mathrm{~S}\right]$ cystine accumulation from the degradation of endogenous labeled protein. Addition of these agents at a concentration of 100 $\mu \mathrm{M}$ to cells prelabeled for either 4 or $24 \mathrm{~h}$ produced inhibition of cystine accumulation of 48 to $72 \%$ (Table II). Inhibition also occurred at $4 \mathrm{~h}$ of incubation after either a 4- or 24-h prelabel. However, due to the slow rate of cystine accumulation, statistical significance is not achieved between control and treated cells during this interval. Not shown in Table II is the effect of these agents on the amount of residual label in the protein pool or in the generation of acid soluble radioactivity. The same effect was seen as in the cycloheximide-treated cells: the amount of acid soluble radioactivity was increased after both the 4-h prelabel ( $29 \%$ increase for puromycin), and 24-h prelabel (24\% increase for emetine, $20 \%$ increase for puromycin). No consistent effect was seen on the amount of radioactivity remaining in the protein pool as was also found in the cycloheximide-treated cells.

The cytoplasmic protease inhibitors L-1-tosylamido-2phenylethyl-chloromethyl ketone (TPCK) ${ }^{1}$ and $N$ - $\alpha$-p-tosyl-Llysine-chloromethyl ketone (TLCK) (1) and bestatin (2) were studied to determine if the labeled cystine accumulation derived from proteins labeled for only $4 \mathrm{~h}$ was related to nonlysosomal proteolysis. After a 4-h label in $\left[{ }^{35} \mathrm{~S}\right]$ cystine and treatment with cysteamine, cells were placed in unlabeled cystine-free medium with or without the addition of both $100 \mu \mathrm{M}$ TPCK and TLCK, or $100 \mu \mathrm{M}$ bestatin, and harvested after $24 \mathrm{~h}$ incubation. The control cells accumulated $2.31 \pm 1.57 \times 10^{4} \mathrm{cpm} / 10^{6}$ cells, whereas the TPCK/TLCK treated cells accumulated $3.05 \pm 2.52$ $\times 10^{4} \mathrm{cpm} / 10^{6}$ cells (mean of two experiments using duplicate plates). In the bestatin experiments, the control cells accumulated $0.61 \times 10^{4} \mathrm{cpm} / 10^{6}$ cells, and the bestatin-treated cells accumulated $0.68 \times 10^{4} \mathrm{cpm} / 10^{6}$ cells. Similar results were observed after only $4 \mathrm{~h}$ of incubation. No inhibition of lysosomal $\left[{ }^{35} \mathrm{~S}\right]$ cystine accumulation was thus produced by these cytosolic protease inhibitors.

To determine if these agents inhibit proteolysis directly, degradation of hemoglobin by cystinotic fibroblast sonicates was measured in the presence of each inhibitor of protein synthesis. Hemoglobin degradation by fibroblast sonicates was $105 \%$ of control in the presence of $125 \mu \mathrm{M}$ cycloheximide, $93 \%$ of control in the presence of $100 \mu \mathrm{M}$ puromycin, and $104 \%$ of control in the presence of $100 \mu \mathrm{M}$ emetine. (Data are the means of duplicate determinations.) No significant inhibition of degradation of this protein was thus produced by these compounds.

1. Abbreviations used in this paper: SDS-PAGE, SDS-polyacrilamide gel electrophoresis; TLCK, $N$ - $\alpha$-p-tosyl-L-lysine chloromethyl ketone; TPCK, L-1-tosylamido-2-phenylethyl chloromethyl ketone. 
Table I. Effect of Cycloheximide on Cystine Accumulation from Endogenous Protein Degradation in Cystinotic Fibroblasts

\begin{tabular}{|c|c|c|c|c|c|c|c|c|c|}
\hline \multirow[b]{2}{*}{$\begin{array}{l}\text { Labeling } \\
\text { period }\end{array}$} & \multicolumn{3}{|c|}{$\begin{array}{l}\left.{ }^{33} \mathrm{~S}\right] \text { Cystine } \\
\left(\mathrm{cpm} / 10^{6} \text { cells } \times 10^{4}\right)\end{array}$} & \multicolumn{3}{|c|}{ Percent acid soluble radioactivity } & \multicolumn{3}{|c|}{$\begin{array}{l}\text { Acid precipitable }\left[^{35} \text { S }\right] \text { cystine } \\
\left(\mathrm{cpm} / 10^{6} \text { cells } \times 10^{4}\right)\end{array}$} \\
\hline & Control & $\begin{array}{l}\text { Cyclo- } \\
\text { heximide }\end{array}$ & Change & Control & $\begin{array}{l}\text { Cyclo- } \\
\text { heximide }\end{array}$ & Change & Control & $\begin{array}{l}\text { Cyclo- } \\
\text { heximide }\end{array}$ & Change \\
\hline & & & $\%$ & & & $\%$ & & & $\%$ \\
\hline $\begin{array}{l}4 \mathrm{~h} \\
(n=4)\end{array}$ & $\begin{array}{l}1.46 \pm 0.50 \\
P<0.01\end{array}$ & $0.34 \pm 0.27$ & -77 & $\begin{array}{l}49.5 \pm 14.6 \\
P<0.05\end{array}$ & $67 \pm 3.2$ & +35 & $\begin{array}{l}12.8 \pm 12.4 \\
P=0.10\end{array}$ & $7.17 \pm 6.3$ & -44 \\
\hline $\begin{array}{l}24 \mathrm{~h} \\
(n=3)\end{array}$ & $\begin{array}{l}2.21 \pm 1.36 \\
P<0.05\end{array}$ & $0.56 \pm 0.29$ & -75 & $\begin{array}{r}41 \pm 7.2 \\
P<0.10\end{array}$ & $52.6 \pm 5.5$ & +28 & $\begin{array}{l}19.5 \pm 5.6 \\
P=\mathrm{NS}\end{array}$ & $19.3 \pm 7.0$ & -1.0 \\
\hline $\begin{array}{l}48 \mathrm{~h} \\
(n=3)\end{array}$ & $\begin{array}{l}3.47 \pm 2.93 \\
P<0.10\end{array}$ & $1.00 \pm 0.89$ & -71 & $\begin{array}{r}37 \pm 7.2 \\
P<0.05\end{array}$ & $48 \pm 1.7$ & +30 & $\begin{array}{l}26.7 \pm 7.8 \\
P=\mathrm{NS}\end{array}$ & $30.1 \pm 4.7$ & +13 \\
\hline
\end{tabular}

60-mm tissue culture dishes of confluent cystinotic fibroblasts were incubated in tissue culture medium containing $37.6 \mathrm{mCi} / \mathrm{mmol}\left[{ }^{35} \mathrm{~S}\right]-\mathrm{cystine}$ for the periods as shown. After the end of the labeling period the radioactive medium was removed and the cells exposed to $1.0 \mathrm{mM}$ cysteamine in cystine-free medium for $30 \mathrm{~min}$. The cells were then washed three times in phosphate-buffered saline and replaced in cystine-free medium for an additional $24 \mathrm{~h}$. They were harvested by trypsinization and the intracellular free $\left[{ }^{35} \mathrm{~S}\right]$ cystine quantified by high-voltage electrophoresis on paper. The results were obtained in two cystinotic cell lines. Each experiment used duplicate plates at each time point. $(n)=$ number of times each experiment was performed. Statistical analysis was by Student's paired $t$ test. NS, not significant.

Exogenous proteins. The effect of cycloheximide on lysosomal cystine accumulation derived from the degradation of extracellular cystine-containing proteins is shown in Table III.

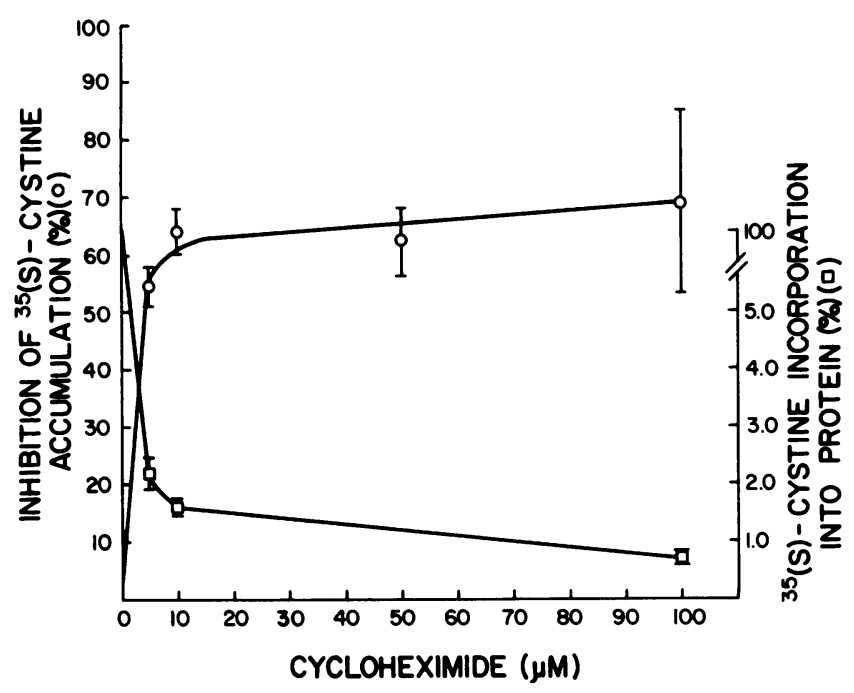

Figure 1. The effect of the concentration of cycloheximide on both $\left.{ }^{35} \mathrm{~S}\right]$ cystine accumulation from cells prelabeled for $24 \mathrm{~h}$ with $\left[{ }^{35} \mathrm{~S}\right]$ cystine and on incorporation of $\left[{ }^{35} \mathrm{~S}\right]$ cystine into protein. Triplicate plates of cystinotic fibroblasts were labeled in $\left[{ }^{35}\right.$ S $]$ cystine containing medium for $24 \mathrm{~h}$, depleted of $\left[{ }^{35} S\right]$ cystine with cysteamine, and placed in unlabeled media containing the indicated concentration of cycloheximide and harvested after an additional 24-h incubation as described in Methods. Points are the mean \pm 1.0 SD of triplicates. Data at the $100-\mu \mathrm{M}$ concentration have been averaged with the corresponding plates shown in Table I. To determine the effect of cycloheximide on incorporation of label into protein, duplicate plates were incubated in $\left.{ }^{35} \mathrm{~S}\right]$ cystine-containing medium $\left(9.1 \times 10^{6} \mathrm{cpm} /\right.$ $\mathrm{ml}, 507 \mathrm{Ci} / \mathrm{mmol}$ ) in the presence of the indicated concentration of cycloheximide and harvested after a 24-h incubation. The cellular proteins were precipitated with $12 \%$ sulfosalicylic acid, the supernatant removed and the pellet dissolved in $0.1 \mathrm{~N} \mathrm{NaOH}$ for liquid scintillation counting. Note scale change between $\left[{ }^{35}\right.$ S $]$ cystine incorporation () and $\left[{ }^{35}\right.$ S $]$ cystine accumulation (O).
We have previously shown that intralysosomal free-cystine accumulation in cystinotic fibroblasts incubated in cystine-free medium occurs from the degradation of cystine-containing proteins added to the culture medium $(3,4)$. The data in Table III show that cystine accumulation from BSA and RNase was not significantly inhibited by cycloheximide, but cystine accumulation from insulin was $(P<0.01)$. In another experiment of the type shown in Table III, cystine-depleted cystinotic fibroblasts were incubated in medium containing $1 \mathrm{mg} / \mathrm{ml}$ insulin with or without the addition of $10 \mu \mathrm{M}$ cycloheximide. After $4 \mathrm{~h}$ incubation the control cells had accumulated 0.67 nmol cystine $/ 10^{6}$ cells, whereas the cycloheximide-treated cells accumulated $0.51 \mathrm{nmol}$ cystine $10^{6}$ cells; after $24 \mathrm{~h}$ the controls had accumulated $2.61 \mathrm{nmol} / 10^{6}$ cells and the cycloheximidetreated cells had accumulated only $0.85 \mathrm{nmol} / 10^{6}$ cells.

Attempts to replicate these experiments using emetine and puromycin were unsuccessful due to cellular detachment and disintegration that occurred when these agents were added to the medium in addition to the extracellular cystine-rich protein. This toxicity is not seen when these proteins are added alone, and cytotoxicity in the absence of these proteins was only seen in the case of emetine (see legend to Table II).

No apparent effect of cycloheximide on insulin binding or release from the plasma membrane receptor was seen in these experiments (see Fig. $2 A$ and $B$ ) when binding of insulin to the plasma membrane was examined at intervals of $0-5 \mathrm{~h}$. Preincubation of cystinotic cells for $24 \mathrm{~h}$ with $10 \mu \mathrm{M}$ cycloheximide also had no effect on binding of ${ }^{125}$ I-insulin to these cells: control cells bound $456 \pm 82.3 \mathrm{cpm} / \mathrm{mg}{ }^{125}$ I-insulin, 100 $\mu \mathrm{M}$ cycloheximide pretreated cells bound $520 \pm 165 \mathrm{cpm} / \mathrm{mg}$ ${ }_{125}$ I-insulin $(P>0.5)$ and $10 \mu \mathrm{M}$ cycloheximide pretreated cells bound $520.6 \pm 363 \mathrm{cpm} / \mathrm{mg}{ }^{125}$ I-insulin $(P>0.5)$. Points are the mean of triplicate plates.

Comparison to normal fibroblasts. Cystinotic fibroblasts appear metabolically normal with the exception of the inability to transport cystine from lysosomes, which results from a defective lysosomal transport system for cystine $(13,14)$. This defect is specific for cystine; no other aminoacid, including 
Table II. Effect of Puromycin and Emetine (100 $\mu M)$ on Cystine Accumulation from Endogenous Protein Degradation in Cystinotic Fibroblasts

\begin{tabular}{|c|c|c|c|c|c|c|}
\hline & \multicolumn{4}{|c|}{$\left[{ }^{33} \mathrm{~S}\right]$ Cystine $\left(\mathrm{cpm} / 10^{6}\right.$ cells $\left.\times 10^{4}\right)$} & \multirow[b]{2}{*}{ Percent inhibition } & \multirow[b]{2}{*}{$P$} \\
\hline & After labeling & After cysteamine & $4 \mathrm{~h}$ & $24 \mathrm{~h}$ & & \\
\hline \multicolumn{7}{|c|}{ 4-h labeling period } \\
\hline Control & 6.49 & 0.20 & 0.37 & 0.61 & - & - \\
\hline Emetine & 6.49 & 0.20 & 0.15 & $*$ & - & - \\
\hline Puromycin & 6.49 & 0.20 & 0.32 & 0.32 & 48 & $<0.05$ \\
\hline \multicolumn{7}{|c|}{ 24-h labeling period } \\
\hline Control & 6.43 & 1.04 & 1.17 & 1.51 & - & - \\
\hline Emetine & 6.43 & 1.04 & 0.61 & 0.42 & 72 & $<0.01$ \\
\hline Puromycin & 6.43 & 1.04 & 0.82 & 0.65 & 57 & $<0.01$ \\
\hline
\end{tabular}

Plates of cystinotic fibroblasts were labeled, cystine-depleted and harvested as in Methods. Duplicate plates were used at each time point, and each experiment has been performed a total of three times using two different cell lines. Statistical analysis was by Students paired $t$ test.

* Cells exposed to emetine after a 4-h label uniformly distintegrated by $24 \mathrm{~h}$. This effect was not seen after a 24-h label and was never seen in cells exposed to cycloheximide or puromycin.

cysteine $(3,15)$ is retained. To ascertain that the degradation of endogenous cystine-containing proteins is the same in cystinotic fibroblasts as in normal cells, the rate of loss of $\left[{ }^{35} \mathrm{~S}\right]$ cystine from the protein pool was measured in both as shown in Fig. 3. After labeling for $48 \mathrm{~h}$, the decline in acid precipitable label that occurs when the cells are placed in unlabeled medium is seen to be the same in both normal and cystinotic cells. This similarity is further demonstrated in Fig. 4 , in which the protein pellets obtained from cells harvested in an experiment like that in Fig. 1 were analyzed by SDSPAGE followed by autoradiography. The distribution of labeled proteins is the same in both normal (lanes 1, 3, and 5) and cystinotic (lanes 2, 4, and 6) fibroblasts at the start of the unlabeled chase, and at 4 and $24 \mathrm{~h}$ thereafter.

\section{Discussion}

Protein degradation is a complex process that may vary with the tissue or cell type studied, the aminoacid and serum content of the medium (complete versus deprivation) and the protein undergoing degradation (extracellular versus intracellular, short versus long half-lived) (16). It appears clear that extracellular proteins that enter the cell via pinocytosis are degraded by the constituitive proteolytic systems within lysosomes. Endogenous proteins appear to be degraded cytoplasmically if they are rapidly turned over and if they are studied under nutritionally complete conditions. The augmented proteolysis of endogenous proteins observed under step-down conditions (media lacking one or more essential aminoacids) is thought to occur primarily in lysosomes, however the mechanisms required to switch loci are unknown. Also problematic is the mechanism required to dissociate insulin from its receptor so that insulin is degraded lysosomally (17) while its receptor is recycled intact to the cell surface (18).

The interference of cycloheximide with the degradation of endogenous proteins has been known for some time. In 1971 Hershko and Tomkins (19) observed that the enhanced deg-

Table III. Effect of Cycloheximide on Cystine Accumulation from Extracellular Cystine-containing Proteins

\begin{tabular}{|c|c|c|c|c|c|c|}
\hline Protein & Concentration & Cycloheximide & Cystine accumulation & Inhibition & Cell lines & \\
\hline & $m g / m l$ & $10^{-4} \mathrm{M}$ & nmol/10 $10^{\circ} \mathrm{cells}$ & $\%$ & & $n$ \\
\hline \multirow[t]{3}{*}{ BSA } & 50 & - & $0.92 \pm 0.90$ & & & \\
\hline & & & $P>0.3$ & 10 & 3 & 5 \\
\hline & & + & $0.83 \pm 0.74$ & & & \\
\hline \multirow[t]{3}{*}{ RNase } & 20 & - & $1.00 \pm 0.59$ & & & \\
\hline & & & $P>0.5$ & 19 & 2 & 4 \\
\hline & & + & $0.81 \pm 0.35$ & & & \\
\hline \multirow[t]{3}{*}{ Insulin } & 1.0 & - & $1.17 \pm 0.66$ & & & \\
\hline & & & $P<0.01$ & 53 & 2 & 5 \\
\hline & & + & $0.55 \pm 0.38$ & & & \\
\hline
\end{tabular}

60-mm tissue culture dishes of confluent cystinotic fibroblasts were depleted of their initial lysosomal cystine content by exposure to $1 \mathrm{mM}$ cysteamine in cystine-free medium for $30 \mathrm{~min}$, washed once in phosphate-buffered saline and replaced in cystine-free medium without fetal calf serum but containing the indicated concentration of each protein. After $24 \mathrm{~h}$ incubation the cells were harvested by trypsinization and the acid soluble supernatant analyzed for cystine by the cystine-binding protein assay. Each experiment employed duplicate plates. $n=$ number of times each experiment was performed. $P$ values were determined by Student's paired $t$ test. The cystine content of the proteins is (mole cystine/mole protein): BSA, 17; RNAse, 4; insulin, 3. 

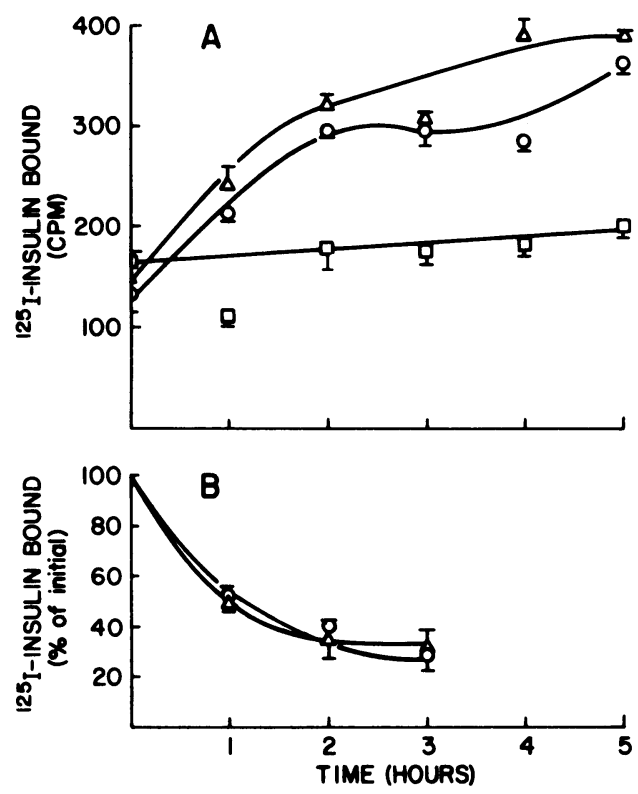

Figure 2. The effect of $100 \mu \mathrm{M}$ cycloheximide on ${ }^{125} \mathrm{I}$-insulin binding $(A)$ and dissociation $(B)$ in cystinotic fibroblasts. Control $(0)$, cycloheximide-treated $(\Delta)$, nonspecific binding $(\square)$. See Methods for details.

radation of glucocorticoid-induced tyrosine amino-transferase at low $\mathrm{pH}(6.5)$ in hepatoma cells was completely inhibited by $100 \mu \mathrm{M}$ cycloheximide. Baccino et al. (20) found that cycloheximide inhibited starvation-enhanced proteolysis in perfused rat livers, and suggested that it acted through suppression of the autophagic process, as well as by decreasing the lysosomal protease system. Ballard found that cycloheximide inhibited protein breakdown in a human breast carcinoma line (T47D) under all conditions, but inhibited breakdown in a rat myoblast line only under control conditions, and increased breakdown of protein if serum were present (21). The effects were also attributed to interference with lysosomal proteolysis. The effect of cycloheximide and other protein synthesis inhibitors on proteolysis in many cell lines was reviewed in 1976 (16).

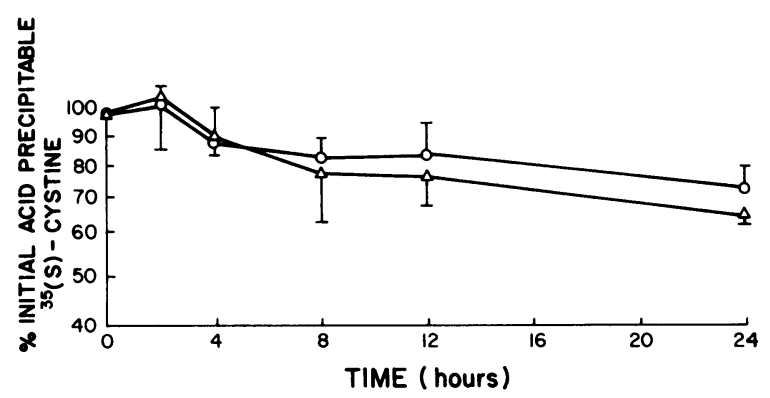

Figure 3. Loss of $\left[{ }^{35} S\right]$ cystine from the protein pool in normal and cystinotic fibroblasts. Plates of normal and cystinotic fibroblasts were labeled for $48 \mathrm{~h}$ in $\left[{ }^{35} \mathrm{~S}\right]$ cystine containing medium $\left(5.2 \times 10^{6} \mathrm{cpm} /\right.$ $\mathrm{ml}, 500 \mathrm{Ci} / \mathrm{mmol} \mathrm{sp}$ act) washed twice in phosphate-buffered saline and replaced in unlabeled medium. Triplicate plates were harvested by trypsinization at each time point, the cell proteins precipitated with $12 \%$ sulfosalicylic acid, and aliquots of the protein pellet dissolved in $0.1 \mathrm{~N} \mathrm{NaOH}$ removed for liquid scintillation counting. Points are the mean \pm 1.0 SD of triplicate plates. $(0)$, normal cells, $(\Delta)$, cystinotic cells. Initial radioactivity was $2.11 \pm 0.19 \mathrm{cpm} / 10^{6}$ cells in the normal cells and $2.43 \pm 0.04 \mathrm{cpm} / 10^{6}$ cells in the cystinotic cells.

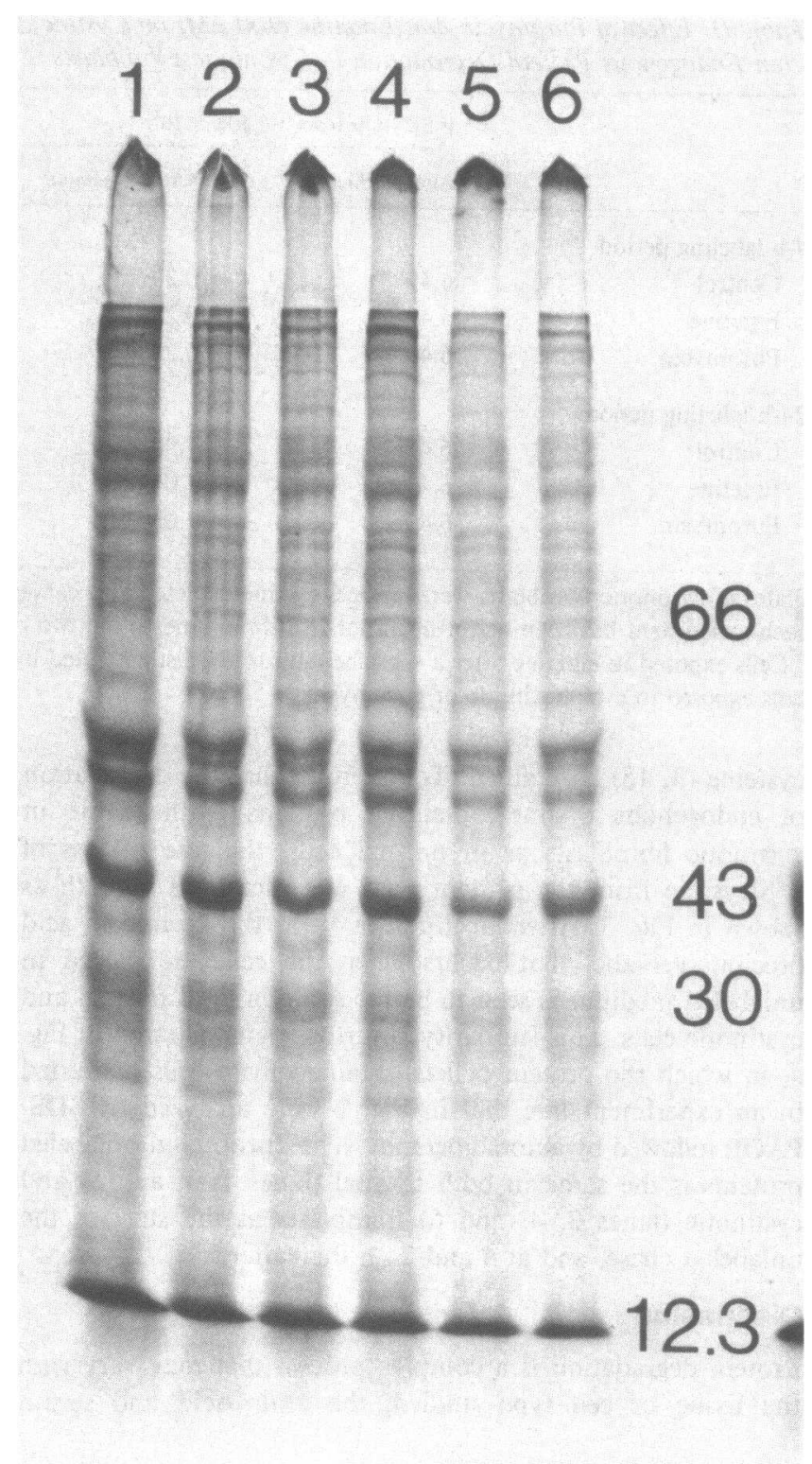

Figure 4. Autoradiography of $\left[{ }^{35} \mathrm{~S}\right]$ cystine labeled proteins from normal and cystinotic fibroblasts. $60-\mathrm{mm}$ plates of normal and cystinotic fibroblasts were incubated for $4 \mathrm{~d}$ in medium containing $\left[{ }^{35} \mathrm{~S}\right]$ cystine. At the end of the labeling period they were washed three times in phosphate-buffered saline, replaced in unlabeled medium, and plates harvested at 0,4 , and $24 \mathrm{~h}$ of incubation. 50- $\mu \mathrm{g}$ aliquots of the labeled cell proteins were then analyzed by SDS-PAGE and autoradiography as described in Methods. Lanes 1, 3, and 5 contain $50 \mu \mathrm{g}$ of protein from normal fibroblasts. Lanes 2,4 , and 6 contain $50 \mu \mathrm{g}$ protein from cystinotic fibroblasts. Lanes 1 and 2 were harvested immediately after the 4-d incubation period. Lanes 3 and 4 were harvested $4 \mathrm{~h}$ after the start of the unlabeled chase, and lanes 5 and 6 were harvested $24 \mathrm{~h}$ after the start of the chase. Molecular weights are indicated at the right of the figure.

In this study we have examined lysosomal proteolysis directly by measuring lysosomal free-cystine accumulation in cystinotic fibroblasts from the degradation of cystine-containing proteins. Since cystinotic fibroblasts degrade $\left[{ }^{35} S\right]$ cystine-labeled proteins in a manner identical to that of normal fibroblasts 
(Figs. 3 and 4), we believe the results obtained in these cells can also be applied to normal fibroblasts incubated under these conditions. Cystinotic fibroblasts incubated in cystinefree medium (which creates a "step-down" condition) (4) accumulate lysosomal cystine only from cystine residues present in proteins undergoing degradation. Cystine accumulation in these cells thus provides a unique opportunity to observe lysosomal proteolysis apart from cytoplasmic proteolysis. We have found that cycloheximide, puromycin, and emetine markedly inhibit lysosomal $\left[{ }^{35} \mathrm{~S}\right]$ cystine accumulation from the degradation of endogenous $\left[{ }^{35} \mathrm{~S}\right]$ cystine labeled proteins, implying the participation of a short half-lived protein in the lysosomal proteolysis of these proteins.

Protein half-lives within cells are widely variable, from $<1$ $\mathrm{h}$ for some enzymes, to several days in structural proteins. The utility of this selectivity in controlling the abundance of certain critical enzymes has been noted (16). Measurement of degradation from a protein pool that has been labeled for a specific period obviously reflects a mean degradation rate that depends upon the relative abundance of all proteins labeled during that period. Using this technique, the data in Table I show that cycloheximide inhibits the degradation of endogenous proteins regardless of labeling period. Lysosomal cystine accumulated from the 4-h-labeled pool, as well as from the 24and 48-h pool (Tables I and II) even after only $4 \mathrm{~h}$ of incubation (Table II). This is consistent with the step-down (cystine-free medium) conditions used in these experiments in which lysosomal degradation of endogenous proteins would be expected. This finding is reinforced by the lack of effect of the cytoplasmic protease inhibitors TPCK and TLCK, and bestatin, on lysosomal-cystine accumulation after the protein pool had been labeled for only $4 \mathrm{~h}$. If degradation were cytosolic, followed by entry of label into the lysosome, bestatin and TPCK and TLCK should have inhibited the observed cystine accumulation: no such inhibition was observed.

The increase in the amount of acid soluble radioactivity produced by the cells in the presence of cycloheximide (Table I) suggests that total proteolysis is not inhibited, but shifted to a nonlysosomal site. The magnitude of this shift cannot be quantified from these data, however, because cycloheximide also inhibits resynthesis of labeled cystine back into the protein pool. For the same reason, whether total cell proteolysis is increased or unchanged under these conditions cannot be determined.

The concentration of cycloheximide required to inhibit maximally the incorporation of $\left[{ }^{35} \mathrm{~S}\right] \mathrm{cyst}(\mathrm{e})$ ine into protein and to inhibit lysosomal degradation of labeled endogenous proteins is the same. $50 \mu \mathrm{M}$ cycloheximide almost completely abolishes protein synthesis and reduces lysosomal $\left[{ }^{35}\right.$ S]cystine accumulation by $\sim 65 \%$ (Fig. 1). Protein synthesis was also inhibited by $>97 \%$ by $100 \mu \mathrm{M}$ concentrations of puromycin and emetine. This concentration of these compounds also inhibited lysosomal cystine accumulation from the 24-h labeled protein pool by 48-72\% (Table II). These data strongly support the hypothesis that protein synthesis is required for the lysosomal degradation of endogenous proteins under step-down conditions regardless of protein half-life, since no inhibitory effect of cycloheximide, emetine, or puromycin on the degradation of hemoglobin by cell sonicates could be demonstrated (see Results).

Extracellular proteins gain access to the interior of the cell either by pinocytosis or receptor-mediated endocytosis. Proteins taken up by pinocytosis may remain in the fluid phase or be adsorbed onto the plasma membrane (22). Although adsorptive pinocytosis may enhance the rate of entry of a protein into the cell, it does not alter its destination, which is into the lysosomal system via fusion of pinosomes with primary (hydrolase-containing) lysosomes.

Albumin and RNase lack specific cell surface receptors and presumably enter the cell via pinocytosis. We have previously shown that addition of such cystine-rich proteins to cultures of cystine-depleted cystinotic fibroblasts produces an increased cystine accumulation that results from the lysosomal degradation of these proteins with retention of the cystine moieties (3). Addition of cycloheximide under these conditions does not impede lysosomal cystine accumulation (Table III), consistent with the constituitive nature of proteolysis within the lysosomal system. Table III also shows that cycloheximide does not interfere with the ability of cystinotic fibroblasts to accumulate cystine since cystine accumulation from BSA and RNase was unimpaired in the presence of $100 \mu \mathrm{M}$ concentration of this agent.

Insulin binds to a cell surface receptor and is internalyzed. Insulin taken up in this manner is degraded lysosomally, whereas the fate of the receptor is uncertain. Recent evidence suggests a dissociation of insulin from its receptor before entry into lysosomes (18). Prior work in a fibroblastic cell line has demonstrated that cycloheximide at concentrations of 1 to $17.5 \mu \mathrm{M}$ causes an accumulation of insulin receptors at the cell surface (23). These cells are different from normal fibroblasts, however in that they contain a large intracellular receptor pool. Other studies using normal fibroblasts found that cycloheximide lengthens receptor half-life by blocking receptor inactivation, but has no effect on receptor internalization (24). In the current study we found that $100 \mu \mathrm{M}$ cycloheximide had no direct effect on insulin binding to or dissociation from the plasma membrane of cystinotic fibroblasts (Fig. $2 A$ and $B$ ), and that pretreatment of cystinotic cells for $24 \mathrm{~h}$ with either 10 or $100 \mu \mathrm{M}$ cycloheximide had no effect on insulin binding to the cell surface (see Results). However, cycloheximide in concentrations of 10 or $100 \mu \mathrm{M}$ inhibits the amount of lysosomal cystine that accumulates from the addition of insulin to these cells. The interpretation of this experiment is difficult, because to produce measurable cystine accumulation a large concentration of insulin is required $(0.1$ to $1.0 \mathrm{mg} / \mathrm{ml})$ that is much greater than that required to saturate all cell surface insulin receptors. Our data are consistent with that of Knutson et al. (24) that cycloheximide interferes with insulin degradation at a step distal to receptor internalization. Since insulin is presumably entering the cell both by pinocytosis and receptor-mediated endocytosis, it is possible that cycloheximide inhibits only the receptor mediated pathways but does not inhibit fluid-phase pinocytosis, consistent with the lack of effect on cystine accumulation derived from BSA and RNase.

Ciechanover et al. have defined ubiqitin as a necessary element for the nonlysosomal degradation of short-lived intracellular proteins under normal conditions (2). Their studies using a temperature-sensitive cell cycle mutant (ts 85 ) indicate that this ATP-dependent-ubiquitin system accounts for the bulk of selective protein degradation under these conditions $(25,26)$. Inhibition of synthesis of a similar protein could account for the interference with lysosomal proteolysis produced by the protein synthesis inhibitors described in the current 
report. It is possible that the lysosomal degradation of receptormediated proteins also shares this pathway since insulin degradation is also inhibited by these agents. Further work is required to identify the putative protein involved and its role in lysosomal degradation of intracellular proteins.

\section{Acknowledgments}

We thank Mrs. Phyllis Newberry and Ms. Cindy Sloan for excellent secretarial and technical assistance, respectively.

This work was supported by grant AM25548 from The National Institutes of Health.

\section{References}

1. Ettlinger, J. D., and A. L. Goldberg. 1977. A soluble ATPdependent proteolytic system for the degradation of abnormal proteins in reticulocytes. Proc. Natl. Acad. Sci. USA. 74:54-58.

2. Herschko, A., and A. Ciechanover. 1982. Mechanisms of intracellular protein breakdown. Annu. Rev. Biochem. 51:335-364.

3. Thoene, J., and R. Lemons. 1982. Cystine accumulation in cystinotic fibroblasts from free and protein-linked cystine but not cysteine. Biochem. J. 208:823-830.

4. Thoene, J., and R. Lemons. 1980. Modulation of the intracellular cystine content of cystinotic fibroblasts by extracellular albumin. Pediatric Res. 14:785-787.

5. Thoene, J., R. Oshima, D. Ritchie, and J. Schneider. 1977. Cystinotic fibroblasts accumulate cystine from intracellular protein degradation. Proc. Natl. Acad. Sci. USA. 74:4505-4507.

6. Thoene, J., R. Oshima, J. Crawhall, D. Olson, and J. Schneider. 1976. Cystinosis: Intracellular cystine depletion by aminothiols in vitro and in vivo. J. Clin. Invest. 58:180-189.

7. Oshima, R., R. Willis, C. Furlong, and J. Schneider. 1974. Binding assays for aminoacids. The utilization of a cystine binding protein from Escherichia coli for the determination of acid soluble cystine in small physiological samples. J. Biol. Chem. 249:6033-6039.

8. Lowry, O., N. Rosebrough, A. Farr, and R. Randall. 1951. Protein measurement with the Folin phenol reagent. J. Biol. Chem. 193:265-275.

9. Laemmli, U. 1970. Cleavage of structural proteins during the assembly of the head of bacteriophage $\mathrm{T}_{4}$. Nature (Lond.). 227:680685.

10. Press, E., R. Porter, and J. Cebra. 1960. The isolation and properties of a proteolytic enzyme, cathepsin $D$, from bovine spleen. Biochem. J. 74:501-514.

11. Rechler, M., and J. Podansky. 1976. Insulin receptors in cultured human fibroblasts. Diabetes. 25:250-255.

12. Gehlerter, T., V. Dilworth, B. Valka, R. McDonald, and E.
Shorry. 1981. Insulin binding and insulin action in fibroblasts from patients with maturity-onset diabetes of the young. Diabetes. 30:940946.

13. Gahl, W., F. Tietze, N. Bashan, R. Steinherz, and J. D. Schulman. 1982. Defective cystine exodus from isolated lysosome-rich fractions of cystinotic leucocytes. J. Biol. Chem. 257:9570-9575.

14. Jonas, A., A. Green, M. Smith, and J. Schneider. 1982. Cystine accumulation and loss in normal, heterozygous, and cystinotic fibroblasts. Proc. Natl. Acad. Sci. USA. 79:4442-4445.

15. Gahl, W., F. Tietze, N. Bashan, I. Bernardini, D. Raiford, and J. Schulman. 1983. Characteristics of cystine counter-transport in normal and cystinotic lysosome-rich leucocyte granular fractions. Biochem. J. 216:393-400.

16. Goldberg, A. L., and A. C. St. John. 1976. Intracellular protein degradation in mammalian and bacterial cells. Part 2. Annu. Rev. Biochem. 45:747-803.

17. Carpentier, J. L., P. Gorden, P. Freychet, A. LeCam, and L. Orci. 1979. Lysosomal association of internalized ${ }^{125}(\mathrm{I})$-insulin in isolated rat hepatocytes. Direct demonstration by quantitative electron microscopic autoradiography. J. Clin. Invest. 63:1249-1261.

18. Marshall, S., and J. M. Olefsky. 1983. Separate intracellular pathways for insulin receptor recycling and insulin degradation in isolated rat adipocytes. J. Cell. Physiol. 117:195-203.

19. Hershko, A., and G. Tomkins. 1971. Studies on the degradation of tyrosine aminotransferase in hepatoma cells in culture: Influence of the composition of the medium and adenosive triphosphate dependence. J. Biol. Chem. 246:710-714.

20. Baccino, F., L. Tessitore, G. Cecchini, M. Messina, M. Zuretti, G. Bonnelli, L. Gabriel, and J. Amenta. 1982. Control of cell protein catabolism in rat liver. Effect of starvation and cycloheximide. Biochem. J. 206:395-405.

21. Ballard, F. J. 1982. Regulation of protein accumulation in cultured cells. Biochem. J. 208:275-287.

22. Lloyd, J. B. 1976. Substrate specificity in pinocytosis and intralysosomal protein digestion. In Proteolysis and Physiological Regulation. Academic Press, Inc., New York. pp. 371-389.

23. Kadle, R., V. Kalter, M. Raizada, and R. Fellows. 1983. Cycloheximide causes accumulation of insulin receptors at the cell surface of cultured fibroblasts. J. Biol Chem. 258:13116-13119.

24. Knutson, V., G. Ronett, and M. D. Lane. 1983. Rapid, reversible internalyzation of cell surface insulin receptors-correlation with insulin-induced down regulation. J. Biol. Chem. 258:1213912142.

25. Ciechanover, A., D. Finley, and A. Varshavsky. 1984. Ubiquitin dependence of selective protein degradation in the mammalian cell cycle mutant ts 85. Cell. 37:57-66.

26. Finley, D., A. Ciechanover, and A. Varshavsky. 1984. Thermolability of ubiquitin-activating enzyme from the mammalian cell cycle mutant ts85. Cell. 37:43-55. 